\title{
Southward shifting of the Tasman Front at 4.4 Ma (early Pliocene): paleobiogeographic and oxygen isotopic evidence
}

\author{
Kuo-Yen Wei \\ Department of Geology, National Taiwan University, Taipei, Taiwan
}

(Received 21 November 1996; Accepted 11 July 1997)

\begin{abstract}
The Tasman Front represents a thermal boundary across the north Tasman Sea located between $31^{\circ} \mathrm{S}$ and $35^{\circ} \mathrm{S}$ over the Tasman Sea Ridge System in the south-west Pacific. Census data of planktic foraminiferal assemblages and oxygen isotopic variations of planktic and benthic foraminifera obtained from three DSDP sites $(284,590 \mathrm{~A}$ and 588$)$ were used to investigate the Pliocene history of the Tasman Front.The results indicate that at about 4.4 Ma the Tasman Front shifted to the south of $31^{\circ} \mathrm{S}$ as reflected by a major change in the biogeographic distribution of planktic foraminifera. This change caused warming of the sea-surface, particularly in the area of DSDP site 590A. Temperature gradients between surface water and intermediate water (indicated by $\Delta^{18} \mathrm{O}$ planktic-benthic) at DSDP590A also increased, suggesting that the site has been subsequently located beneath a more vertically stratified water column than prior to $4.4 \mathrm{Ma}$.The southward shifting of the Tasman Front might have been a response to the intensification of the East Australian Current, and the enlargement of the West Pacific Warm Pool in the western equatorial Pacific. Both of these oceanographic developments may have been caused by the curtailing of the westerly flowing South Equatorial Current due to tectonic closure of the New Guinea Seaway involving northward motion of the Australian Plate and an associated Pliocene orogeny in central New Guinea. (C) 1998 Published by Elsevier Science Ltd. All rights reserved
\end{abstract}

\section{Introduction}

Marine plankton are strongly influenced by jets and eddies that form an integral part of oceanic fronts, and distinct transitional fauna and flora take advantage of the frontal zone ecotone (Brandt and Wadely 1981). Enhanced phytoplankton biomass is also frequently found along meanders and eddies associated with frontal systems (Strass 1992). Various physical and biologic interactions in the frontal zone lead to strong cross-frontal gradients in species composition, depth distribution and plankton biomass. Larger-scale biogeographic patterns of planktic life tend to follow the basic geometry shaped by frontal zonation (Backus 1986). The Tasman Front in the south-west Pacific displays these patterns and separates the Subtropical planktic biota from a Transitional biota (Eade 1973, Bé and Toderlund 1971).

The Tasman Front (Denham and Crook 1976, Stanton 1979) is a thermal front with an associated eastward zonal jet extending across the northern Tasman Sea from the East Australian Current area to North Cape, New Zealand (Fig. 1). The Front is observed as an abrupt change of temperatures at all depth between the surface and $300 \mathrm{~m}$ (Andrews et al. 1980). It takes a circuitous route, meandering between the latitudes $31^{\circ} \mathrm{S}$ and $35^{\circ} \mathrm{S}$ over the Lord Howe Rise and Norfolk Ridge (collectively known as the Tasman Sea Ridge System) (Stanton 1981, Heath 1985). The mixture of warm water from the East Australian Current/Coral Sea and cool water of the Tasman Sea
(Andrews et al. 1980) results in a complicated pattern of eddies, and characterizes the Tasman Front as a band of high variance in sea surface temperature (Tate et al. 1989). The band is wider at the western end and tapers off eastward. These warm-water eddies have a deep structure that extends from the sea surface to abyssal depths (Mulhearn 1983, Mulhearn et al. 1986). It is estimated that half of the Eastern Australian Current is transported to the east by the Tasman Front (Stanton 1981).

The position of the front is influenced by the variability of the East Australian Current as well as the topographic effects of the Tasman Sea Ridge system (Stanton 1981, Heath 1985). The eastward flow is enforced while it encounters the bathymetrically shallower topographic bottom of the Lord Howe Rise and the Norfolk Ridge (Heath 1985). In particular, the Front tends to loop northward over the Lord Howe Rise, and passes the Rise between $32^{\circ} 20^{\prime} \mathrm{S}$ and $34^{\circ} 30^{\prime} \mathrm{S}$ (Mulhearn 1987).

Viewing New Zealand as a meridional barrier in the south-west Pacific circulation, Warren (1970) suggested that such a zonal jet (the Tasman Front) must exist to link the East Australian Current to the western boundary currents off New Zealand's east coast. The western end of the Tasman front at Sugarloaf point marks the location where the East Australian Current turns seaward from the Australian coast. Godfrey et al. (1980) suggested that the exact turning-off location is determined by the topographic control of the bend in the coastal line of Australia. 


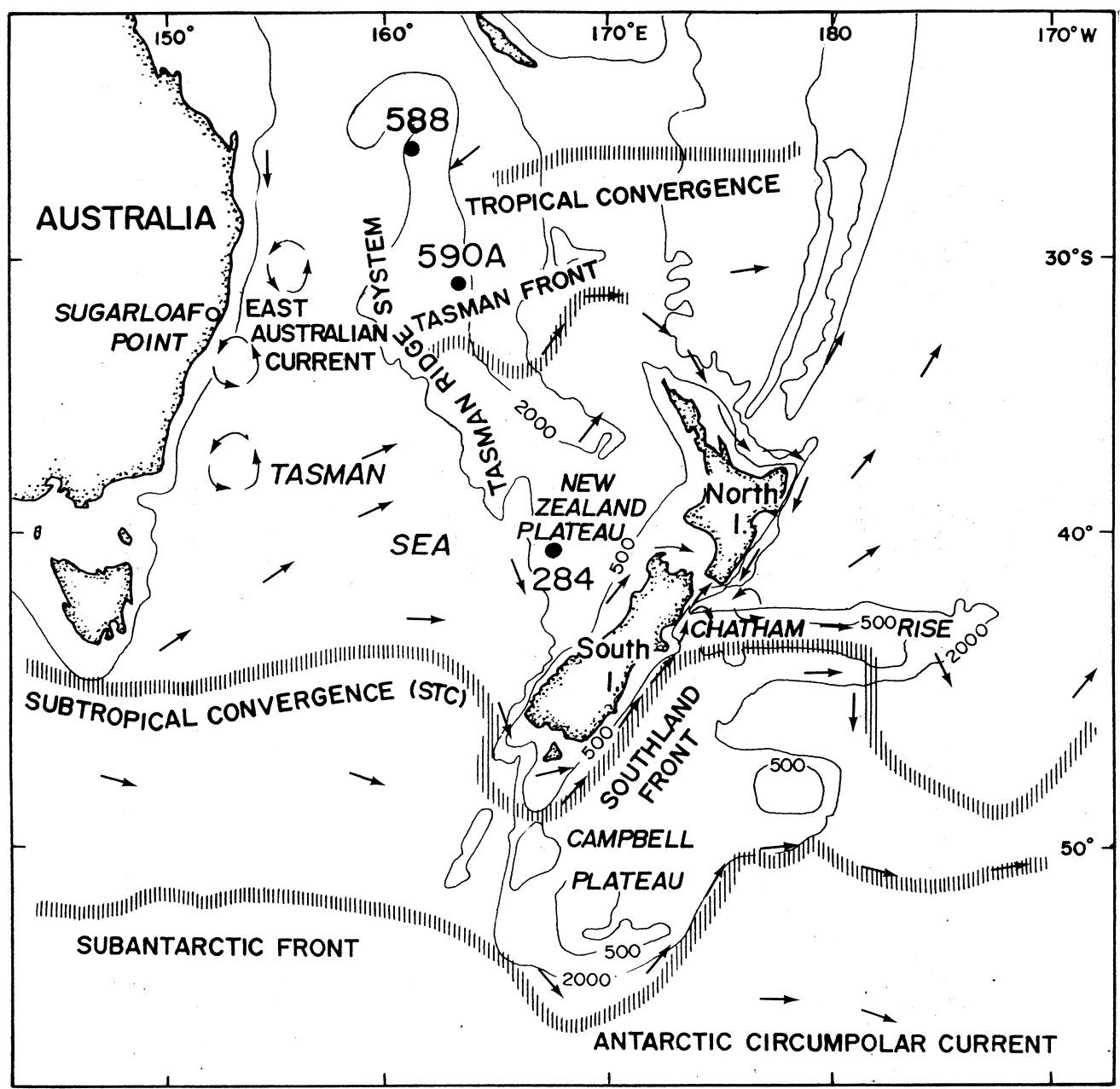

Fig. 1. Location map of the studied DSDP sites in the south-west Pacific, showing circulation pattern, major oceanographic fronts and sea-floor topography. The base map was modified after Fig. 1 of Bradford-Grieve et al. 1991.

The purpose of this paper is to review the Pliocene paleoceanography in the south-west Pacific with special focus on the latitudinal migration of the Tasman Front. The sites studied include three DSDP cores: Site $284\left(40^{\circ} 31^{\prime} \mathrm{S}, 167^{\circ} 41^{\prime} \mathrm{E}\right.$, at water depth of $1066 \mathrm{~m})$, Site $590 \mathrm{~A}\left(31^{\circ} 10^{\prime} \mathrm{S}, 163^{\circ} 22^{\prime} \mathrm{E}\right.$, water depth $1299 \mathrm{~m})$ and Site $588\left(26^{\circ} 06^{\prime} \mathrm{S}, 161^{\circ} 13^{\prime} \mathrm{E}, 1533 \mathrm{~m}\right)$ (Fig. 1).

\section{Biogeographic settings, general paleoceanographic history and working hypotheses}

Geographic distribution of planktic foraminifera and calcareous nannoplankton in the Tasman Sea region is closely related to the surface circulation (Kustanowich 1962, Parker and Berger 1971, Eade 1973, Bé 1977, Andrijanic 1988, Martínez 1994). The sharpest faunal boundary observed by Kustanowich (1962) was in the so-called "north central fauna". This boundary fauna is present between $\sim 32^{\circ} \mathrm{S}$ and $\sim 37^{\circ} \mathrm{S}$ along the northern tip of New Zealand, coinciding with the meandering region of the Tasman Front. Parker and Berger (1971) applied a cluster analysis to delimit faunal provinces in this area. A major cluster boundary was found near $\sim 31^{\circ} \mathrm{S}$, separating clusters A-D from clusters $\mathrm{H}-\mathrm{K}$. They also documented that the left-coiling forms of Neogloboquadrina pachyderma dominate south of $\sim 40^{\circ} \mathrm{S}$. Bé (1977), in a world-wide compilation, further confirmed such provincialism, and coined the Subtropical, Transitional and Subantarctic foraminiferal provinces for the different faunal assemblages. Similar results were attained by Eade (1973) and Hayward (1983). Andrijanic (1988) showed the coincidence of the Tasman Front with the Subtropicaltransitional province boundary. The seasonal migration of warm-water rings derived from the East Australian Current and variations of the Tasman Front are also reflected by foraminiferal distributions (Andrijanic 1988). More recently, Martínez (1994) once again identified three planktic foraminiferal assemblages corresponding to three hydrographic modes in this area. By employing foraminiferal faunal changes, Martínez (1994) was able to reconstruct the position of the Tasman Front and documented the northward migration of the Front during the last Glacial Maximum. Martínez (1994) suggested that this northward migration may indicate a reduction in the volume of the WPWP and/or an increase in the strength of subtropical currents. 
DSDP Site 284 is situated in the central part of the Tasman Sea, recording the faunal variations of the Transitional fauna through time. Site 590A, located to the north of the current position of the Tasman Front, is considered to be a good site to monitor the latitudinal migration of the Front in the geologic past. Site 588 , located at the northern end of the Subtropical faunal province, serves as a monitor of the warm subtropical end-member in this study.

The early Pliocene (between $\sim 5.0$ and $4.2 \mathrm{Ma}$ ) was a period of global warmth and high sea-level (Ciesielski and Weaver 1974, Keany 1978, Hodell and Kennett 1986, Hodell and Warnke 1991). In addition, the volume of Antarctic ice volume and the extend of sea ice may have been less than today (Webb et al. 1984, Webb and Harwood 1991, Hodell and Venz 1992). A distinct mid-Pliocene cooling in the Antarctic surface waters occurred between $\sim 3.5$ and $3.2 \mathrm{Ma}$ as evidenced by an increase in $\delta^{18} \mathrm{O}$ and by faunal changes in ODP Site 704 (Hodell and Warnke 1991, Hodell and Venz 1992).

Four working hypotheses are proposed here against which available foraminiferal and isotopic data will be tested:

(1) The Tasman Front should have acted as a biogeographic boundary in the past as it does today. If the Tasman Front did shift southward during the Pliocene, it is expected that prior to the shift, the faunal composition of Site 590A would resemble that of Site 284 and become similar to that of Site 588 after this event. Moreover, some of the temperate species in DSDP 590A foraminiferal assemblages should be replaced by subtropical components.

(2) The Tasman Front is characterized by the conjunction of the water from the warm South Coral Sea and the cool Tasman Sea and hence should display high variance in temperature. In reference to faunal compositions documented in the Subtropical Convergence Zone (Bary 1959), it is likely that the planktic foraminiferal assemblages at the Tasman Front itself would be comprised of both warm- and cool-water species with an increase in opportunistic (or eurytopic) species which are adapted to the highly variable front ecotone.

(3) At present, the temperature difference in the surface waters across the Front is about $4^{\circ} \mathrm{C}$. If the Tasman Front had shifted from a previously northern position, for example, at $30^{\circ} \mathrm{S}$, to the south of $31^{\circ} \mathrm{S}$, the planktic $\delta^{18} \mathrm{O}$ values in DSDP 590A should become lighter by as much as 1 per million (assuming the $\delta^{18} \mathrm{O}$ of sea waters had kept constant) because this site was then bathed in warmer subtropical water masses. The vertical temperature gradients are also expected to be larger for the water columns to the north of the Tasman Front than in the southern side of the Front. This is because the water columns in low latitudes are more thermally stratified than those in high latitudes.

(4) The Tasman Front is expected to shift to the south when the West Pacific Warm Pool (WPWP) expands. The expansion of the WPWP could be the result of a warm-up of the western equatorial Pacific and/or pile-up of warm water as a consequence of the blockade of the westerly flowing South Equatorial Current, due to closure of pre-existing seaways in the New Guinea area.

\section{Data and methods}

Stable oxygen isotopic data and chronological correlation

Three sources of stable isotopic data have been compiled: (1) For the DSDP Site 284, planktic isotopic values are from Globigerina quinqueloba analyzed by Kennett et al. (1979). G. quinqueloba was considered to be the most consistent marker of the near-surface water isotopic changes among the three species analyzed by Kennett et al. (1979). Benthic values are those of Shackleton and Kennett (1975), augmented with additional analyses by Hodell and Kennett (1986). The benthic foraminifera species analyzed was Uvigerina peregrina. (2) The oxygen stable isotopic data of Site 588 are from Kennett (1986). The planktic isotopic values were measured from Globigerinoides quadrilobatus. The species is a near-surface dweller that precipi-
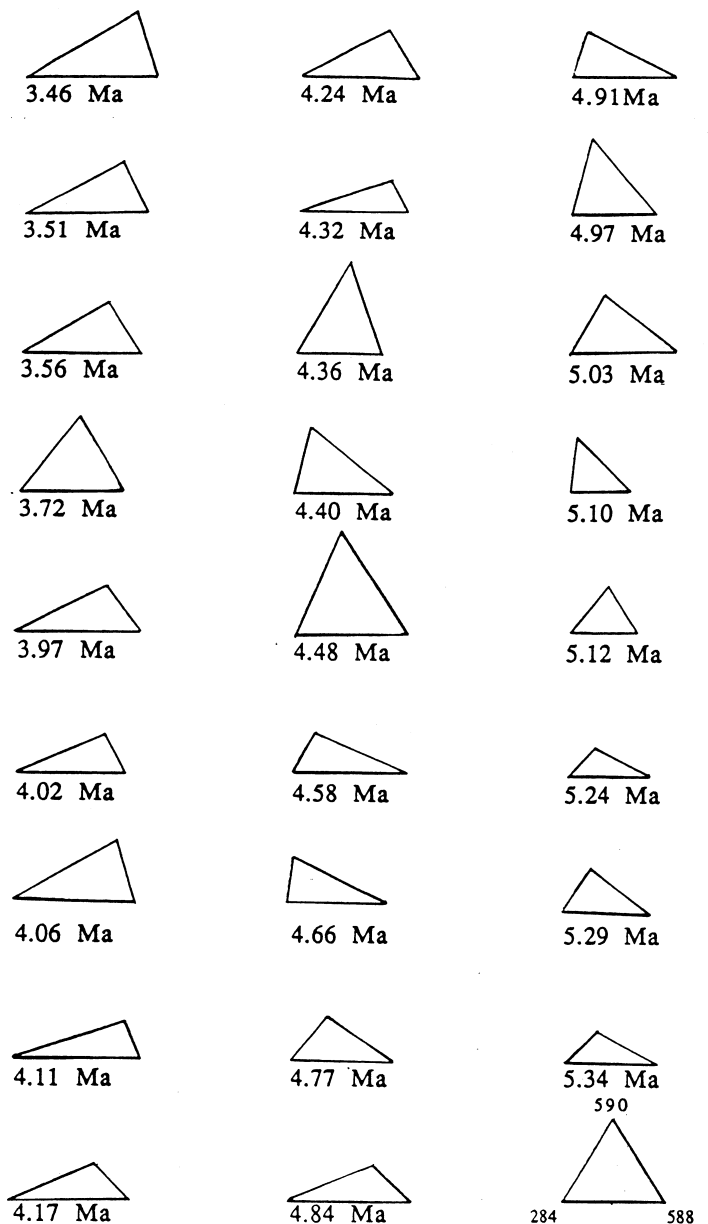

Fig. 2. Dissimilarity triangles showing the planktic foraminiferal faunal difference among DSDP sites 284, 588 and 590A during the late Miocene (5.34-5.0 Ma) and early Pliocene (5.0-3.4 Ma). 
tates its test at a constant offset from oxygen isotopic equilibrium (Williams et al. 1977). Benthic values are from Planulina wuellerstorfi and/or Cibicidoides kullenbergi. (3) Stable isotopic ratios of Site 590A were measured on the benthic foraminifera Cibicidoides kullenbergi and the planktic species Globigerinoides sacculifer (Elmstrom 1985, Elmstrom and Kennett 1986).

The vertical temperature gradients at each site are reflected by the oxygen stable isotopic gradients between the planktic foraminifera and benthic foraminifera. Since the depths of the three studied sites are in the range of $1050-1550 \mathrm{~m}$, the benthic isotopic values are considered to reflect the temperature $/ \delta^{18} \mathrm{O}$ of Antarctic Intermediate Waters, assuming that the benthic foraminiferal tests were precipitated under isotopic equilibrium.

It had once been troublesome to establish an unambiguous correlation between temperate sites (e.g. DSDP 284) and warm subtropical sites (e.g. DSDP 588). Recent advances in using magnetic polarities and chemostratigraphic markers to calibrate high-resolution plankton biostratigraphy has resulted in an adequate magneto-bio-chronological framework for the south-west Pacific (see review by Hodell and Kennett 1986). Magnetic polarity sequences were established for the last $13 \mathrm{my}$ for the DSDP 588 and $3.5 \mathrm{my}$ for the DSDP 590A (Barton and Bloemendal 1986). The magnetostratigraphy of the DSDP 588 has been used as a reference to construct a chronological framework for all the sites studied (Wei and Kennett 1988, Wei 1992). The ages of polarity boundaries and various nannofossil and planktic foraminiferal datum levels were adopted from Berggren et al. (1985). A detailed account of the biochronological correlation was presented in Wei and Kennett (1988).

\section{Foraminiferal fauna data and statistical methods}

The faunal census data of planktic foraminifera were obtained from Elmstrom (1985) for DSDP sites 588 and 590A, and from Kennett and Vella (1975) for DSDP site 284. To measure the faunal difference among the three sites, a dissimilarity index called chord distance is calculated for each pair of samples of the same age. Chord distance is determined by projecting the two samples under comparison onto to a circle of unit radius through the use of direction cosines, and measuring the distance of the chord that connects the two sample points (Pielou 1984, p. 48, Ludwig and Reynolds 1988, p. 170). The chord distances have been calculated for 26 time-slices ranging from 5.34 to 3.46 $\mathrm{Ma}$, and depicted as the three sides of a triangle to indicate the dissimilarities among the three sites during each time slice (Fig. 2). The area of each triangle indicates the overall biogeographic differentiation among the three sites.

\section{DSDP 590A, $31^{\circ} \mathrm{S}$}

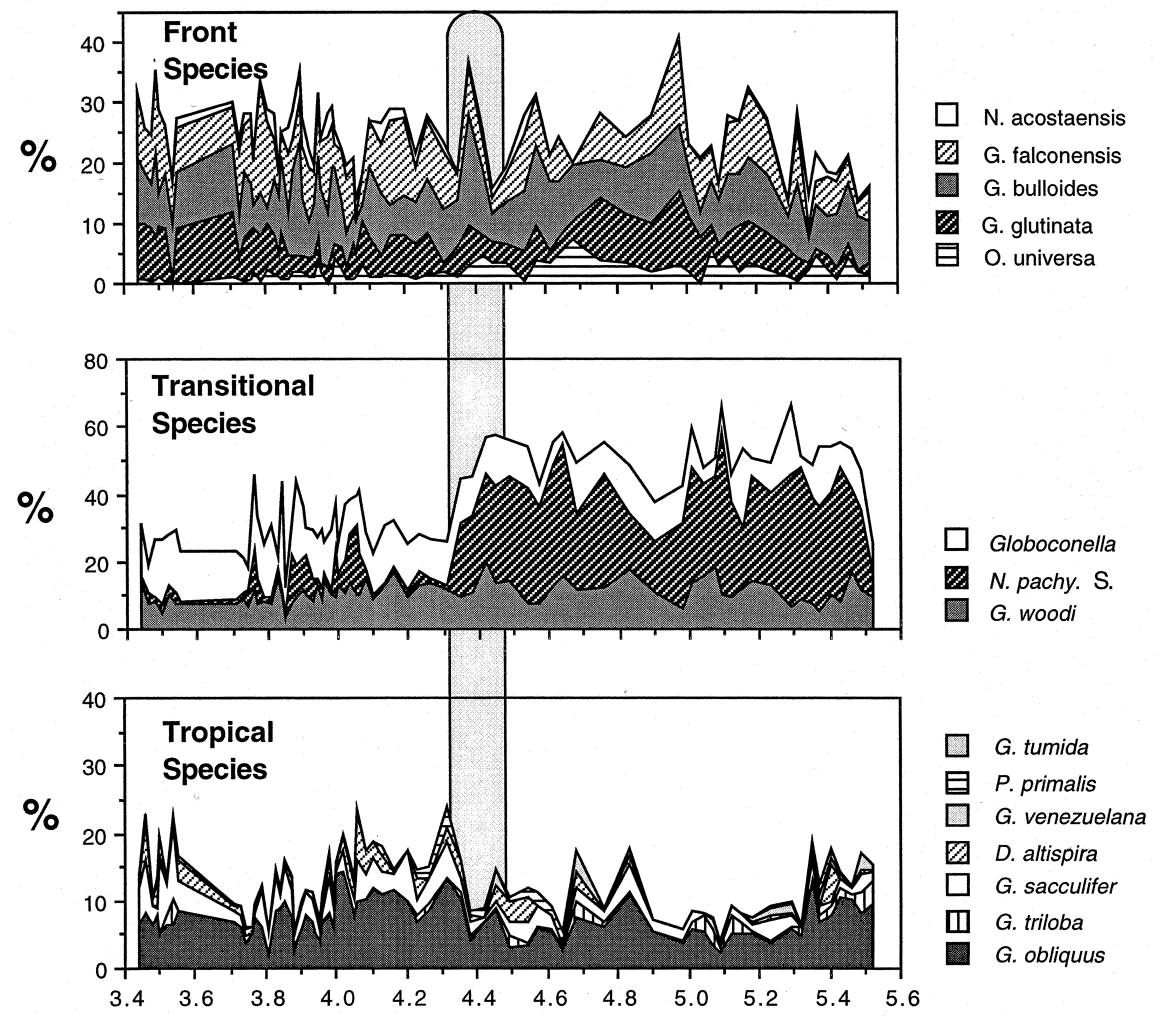

AGE (Ma)

Fig. 3. Planktic foraminifera faunal variation in DSDP 590A. 
The faunal composition has been subdivided into three major categories: tropical, transitional and front species. The classification was mainly based upon the biogeographic delineation of Andrijanic (1988). Species which show relatively high abundance between latitudes $31^{\circ}-34^{\circ} \mathrm{S}$ were grouped as front species. These species include Globigerina bulloides, Neogloboquadrina acostaensis, Globigerina falconensis, Globigerinita glutinata and Orbulina universa.

\section{Results}

\section{Planktic foraminiferal fauna}

With the assumption that the planktic foraminiferal faunal compositions of DSDP sites in the same water mass would be similiar to each other, the similarity depicted by the triangles (Fig. 2) reveals the changing associations of the three sites in terms of their oceanographic settings. The sizes of the triangles, representing the variability of overall dissimilarity among the three sites, increase through time. For intervals prior to 5.03 Ma (i.e. during the late Miocene) the triangles are smaller, indicating smaller biogeographic differentiation in the south-west Pacific. During the early Pliocene (5.0-3.4 Ma) intervals, not only do the sizes of the triangles increase, but change in shape. Before 4.5 $\mathrm{Ma}$ the triangles are skewed to the right, indicating that the faunal compositions of DSDP 590A were similar to those found at temperate site DSDP 284. This suggests that DSDP 590A was then located in the same biogeographic province with site DSDP 284. For time-slices $4.48 \mathrm{Ma}$ to $4.36 \mathrm{Ma}$, the triangles reach maximum size, and show equal dissimilarity among the three sites. It appears that during this period, DSDP 590A was under strong influence of the Tasman Front, reflected by high abundances of front species (Fig. 3). After 4.32 Ma the triangles are skewed to the left, faunal compositions at site 590A became similar to those of warm subtropical site DSDP 588. Thus, it is interpreted that DSDP 590A has been located to the north of the Tasman Front and bathed in the warm subtropical water masses since 4.3 Ma.

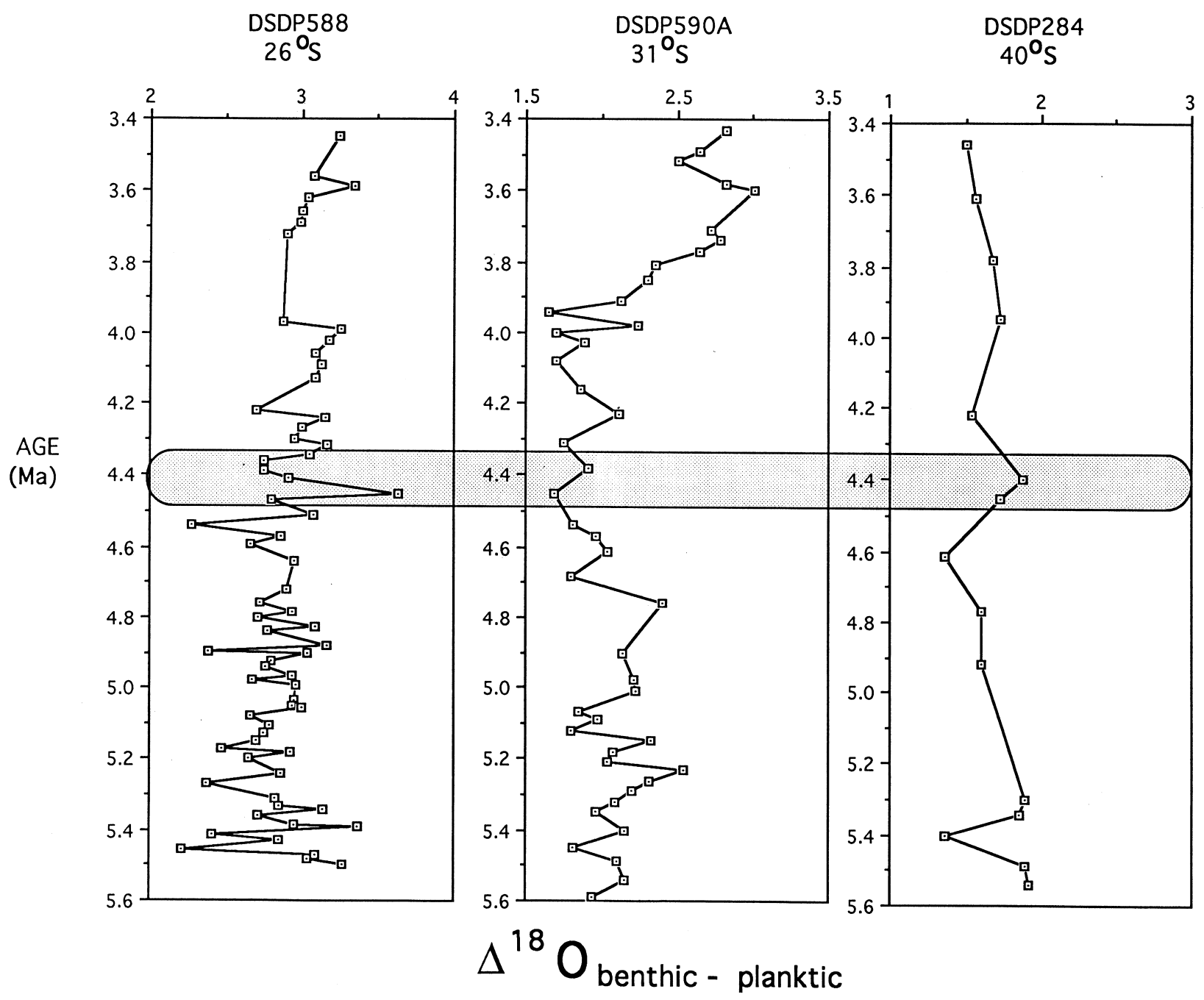

Fig. 4. Oxygen isotopic gradients between planktic and benthic foraminifera in the three studied DSDP sites. Oxygen isotopic values are relative to Pee Dee Belemnite (PDB) standard and are not corrected for species departure from equilibrium. The stippled bar marks the time interval during which the Tasman Front shifted southward. Data resources are mentioned in text. 


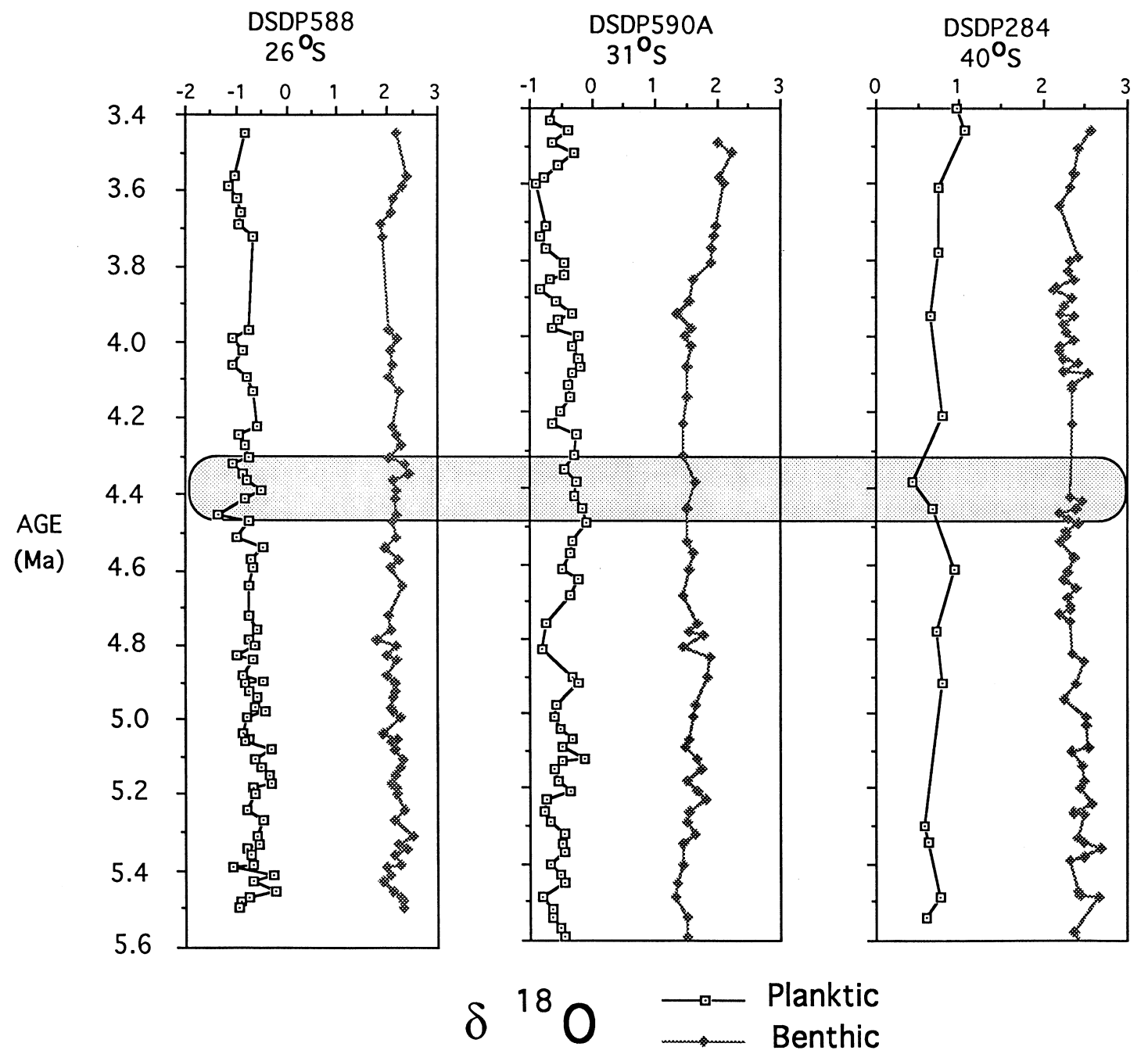

Fig. 5. Time-series of $\delta^{18} \mathrm{O}$ of planktic and benthic foraminifera obtained from DSDP site 588, 590A and 284.

At DSDP 590A, transitional species decreased sharply during 4.5 to $4.3 \mathrm{Ma}$ whereas the tropical elements increased dramatically at the same time (Fig. 3). The front species fluctuated in their relative abundance through time without showing any major trends, however, they do show an abundance peak at about 4.4 Ma. At the same time, sinistral forms of $N$. pachyderma undergo drastic reduction in abundance at DSDP 590A. Dextral forms of the same species occurred after 4.32 Ma (Elmstrom 1985). Such a phenomenon did not occur in site 284 (Kennett and Vella 1975), suggesting the shifting dominance from sinistral forms to dextral forms in $N$. pachyderma at 4.4 Ma is unique at the DSDP 590A. The faunal compositional change centered at $4.4 \mathrm{Ma}$ is considered to be compelling evidence for the proposed shifting of the Tasman Front at 4.4 Ma.

\section{Oxygen isotopes}

For the studied time interval from 5.6 to $3.4 \mathrm{Ma}$, the oxygen isotopic gradients between the surface and bottom waters at DSDP 588 remained close to 1.5 per million, corresponding to a temperature gradient of $12^{\circ} \mathrm{C}$ while the temperature gradients at DSDP 284 were about $7^{\circ} \mathrm{C}\left(\Delta^{18} \mathrm{O}=1.8\right.$ per million) (Fig. 4). Such a difference in vertical temperature gradient could be indicative of different oceanographic settings, namely, warm subtropical and temperate settings. Beginning at 3.9 Ma, there was a step-wise increase in $\Delta^{18} \mathrm{O}$ at DSDP 590A, signaling an increase in vertical temperature gradient from 7 to $11^{\circ} \mathrm{C}$. This change in vertical temperature gradient suggests that DSDP site 590A was first situated in temperate water masses and later bathed in warm subtropical waters. The increase in sea surface temperature was gradual. From 4.5 to 3.6 $\mathrm{Ma}$, the planktic $\delta^{18} \mathrm{O}$ decreases from -0.2 to -1.0 per million, signaling a warming of at least $3^{\circ} \mathrm{C}$ given that all other benthic and planktic $\delta^{18} \mathrm{O}$ time-series in the three sites show a positive trend.

In summary, the oxygen isotopic evidence suggests that the DSDP site 590A underlay different water masses before and after 4.4 Ma. The main evidence is manifested in the gradual warming of the surface waters and a probable gradual cooling of the intermediate waters at this site since 4.3 Ma. Such a contrast resulted in an obvious increase in vertical temperature gradient shown by site 590A (Fig. 4). The increase of sea-surface temperature at DSDP 590A 


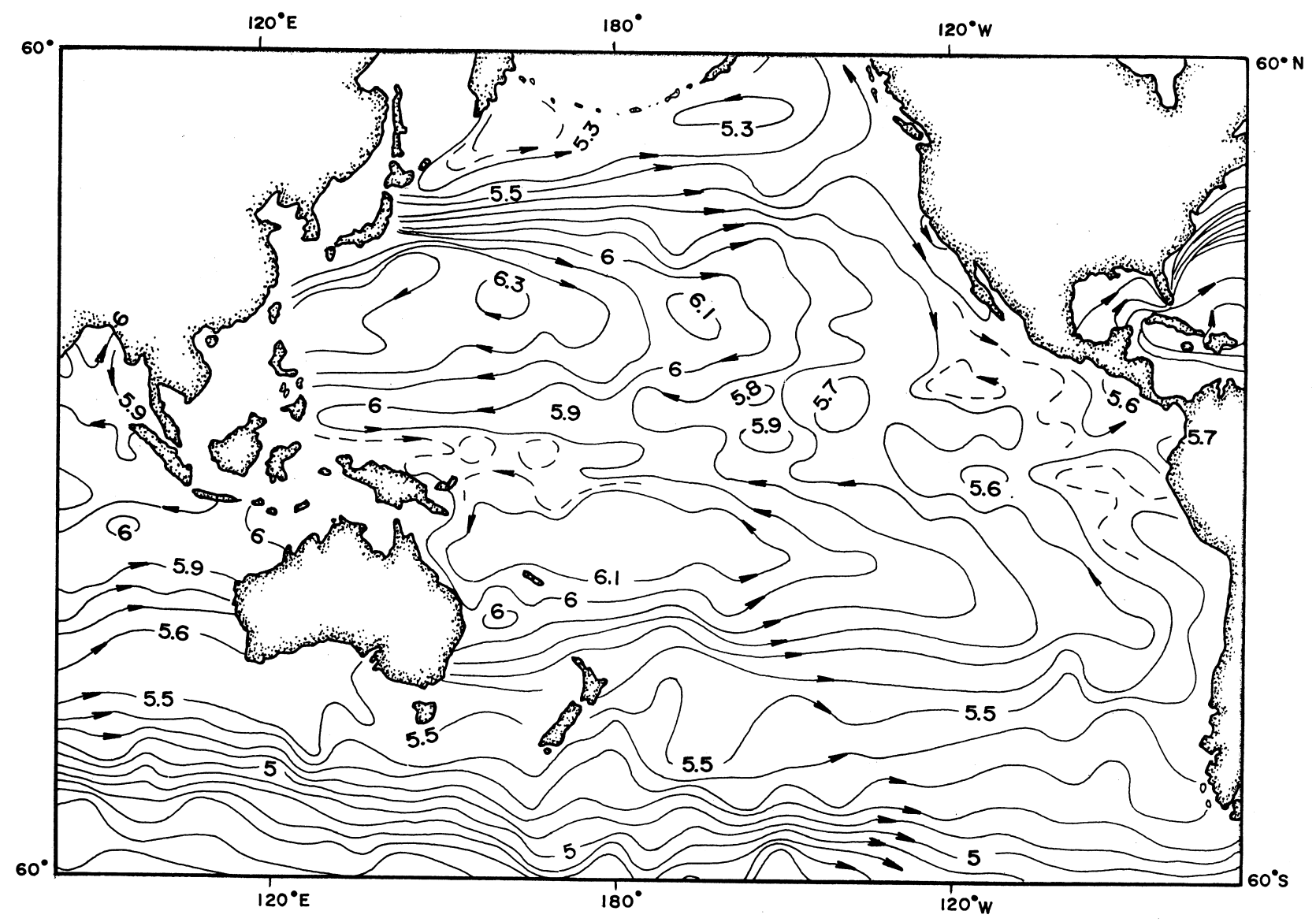

Fig. 6. Dynamic topography of the sea-surface relative to $1500 \mathrm{dbar}$ and the corresponding geostrophic current flow pattern in the mid and low latitudes of Pacific (modified after Fig. 3.11B, Reid 1981).

was at least $3^{\circ} \mathrm{C}$ (Fig. 5), consistent with the prediction of hypothesis 3 .

\section{Discussion}

At present, the westerly flowing South Equatorial Current is driven by the trade winds and blocked by New Guinea (Fig. 6Fig. 7). The pile-up of warm equatorial water in the western Pacific results in the largest single expanse of warm water on our planet, known as the Western Pacific Warm Pool (WPWP). Any variation in the size of the WPWP, and hence the strength and volume of the southward flow would certainly determine the position of the Tropical Convergence and the Tasman Front in the geologic past. Here, I propose that the northward motion of the IndoAustralia Plate and orogenic events of New Guinea during the late Neogene played a vital role in the final closure of the Indonesian Seaway, where the Pacific Equatorial Current flowed into the Indian Ocean (Fig. 7).

It has been suggested that the Equatorial Undercurrent first developed about 12-11 Ma (van Andel et al. 1975, Kennett et al. 1985). Major orogeny first occurred in eastern New Guinea during the middle Miocene (Audley-Charles et al. 1972). By 11$12 \mathrm{Ma}$, New Guinea, together with the Borneo and Indonesian land masses, had became barriers, blocking
Pacific equatorial current from transporting waters into the Indian Ocean. The barrier would have caused the onset of the pile-up of warm surface waters in the western equatorial Pacific and hence the development of western boundary currents and a easterly flowing Equatorial Undercurrent (Kennett et al. 1985). According to the most recent paleogeographic reconstruction of this area by Lee and Lawver (1995) (Fig. 7), prior to $5 \mathrm{Ma}$, the South Equatorial Current was not totally blocked by New Guinea and continued to flow into the Indonesian area. Two passages might exist: one being the seaway located to the north of New Guinea, and the other the pre-existing gateway running through central New Guinea (i.e. the present Ramu-Markham suture zone, marked by the dashed lines in Fig. 7). The Ramu-Markham suture zone is considered to be the north-west continuation of the Solomon Basin (Abbott 1995), which is now being doubly subducted to the north at the New Britain Trench and to the south-west at the Trobriand Trough (Hamilton 1979). Therefore, these tectonic events in New Guinea, and the position of the northern leading edge of the Australian Plate, had the capacity to finetune the circulation patterns of the westernmost South Equatorial Current.

It is possible that at about $4.4 \mathrm{Ma}$, orogeny in central New Guinea caused a final closure of the "Central New Guinea Seaway" while the progressive northward movement of the Australian plate would have also 

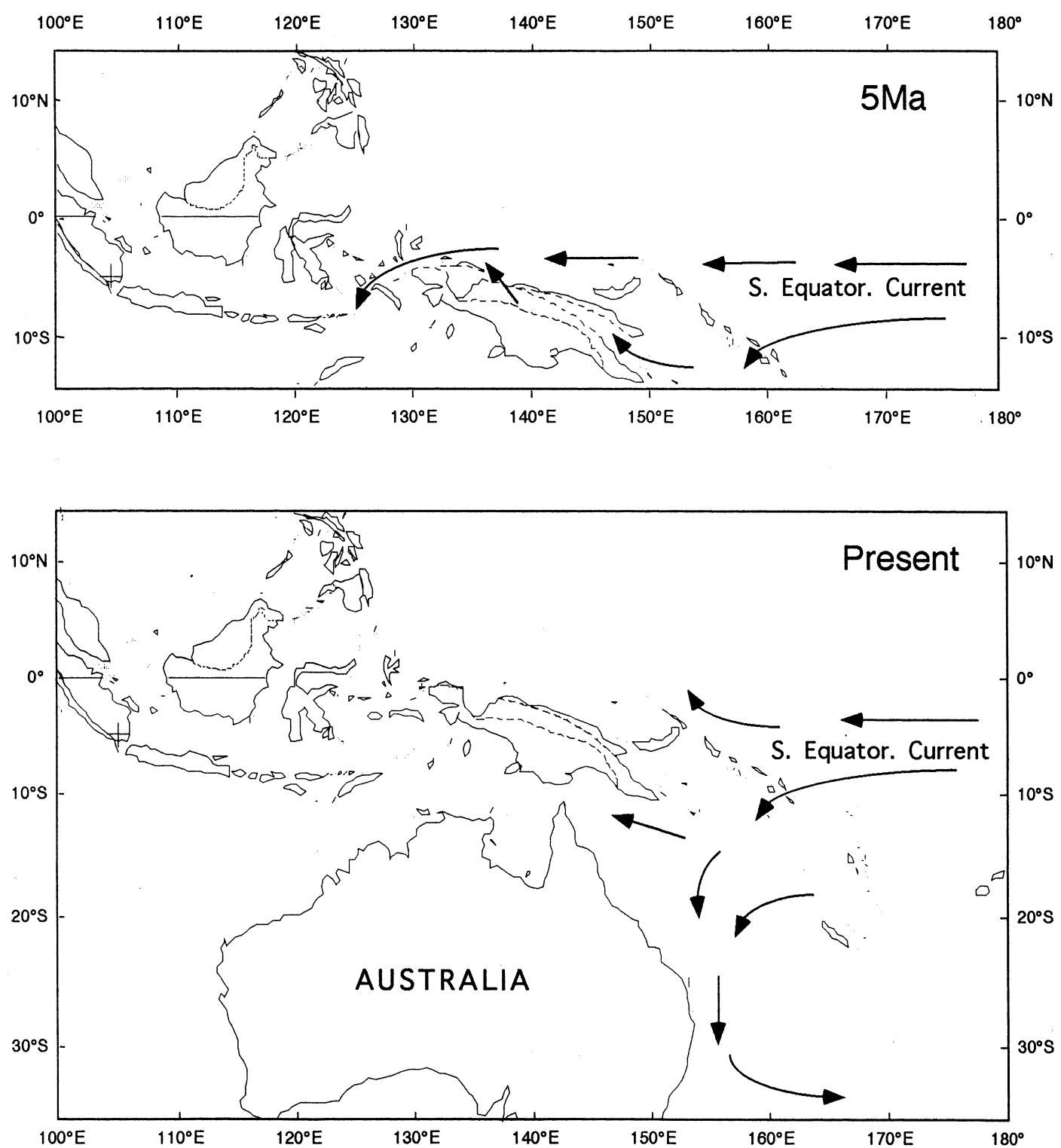

Fig. 7. Upper panel: Hypothetical circulation pattern in the western Equatorial Pacific at 5 Ma. The geographic reconstruction is after Lee and Lawver (1995). The dashed lines in the central New Guinea represent the pre-existing seaway, which has been gradually closed during the last $5 \mathrm{my}$ due to plate subduction. Lower panel: Today's circulation pattern in the south-west Pacific. Note that the westerly flowing South Equatorial Current is forced to bifurcate as it encounters New Guinea.

brought the continents to a critical position so to curtail the South Equatorial Current from flowing to the west. Both of these tectonic developments could have enhanced the pile-up of the Western Pacific warm Pool and hence pushed the Tasman Front to the south.

\section{Conclusions}

Detailed study of the oxygen stable isotope stratigraphy and variations in planktic foraminifera at three DSDP sites (DSDP 284, 588, 590A) in the south-west Pacific suggest that prior to $4.4 \mathrm{Ma}$ the Tasman Front was located to the north of its current position, and shifted south of $31^{\circ} \mathrm{S}$ after this time. The southward shift of the Front might be related to an enhanced pile-up of the Western Pacific Warm Water and the intensification of the East Australian Current due to tectonic developments in the New Guinea area. It is speculated that the northward motion of the Australian Plate and the associated middle Pliocene orogeny in central New Guinea might have played a vital role in the final closure of the west Pacific equatorial seaway, through which the South Equatorial Current flowed westward prior to 4.4 Ma.

Acknowledgements - I am grateful to Prof. Nishimura for his generous invitation and encouragement to attend the Oji Seminar. The interpretations presented in this paper would not have been possible without the assistance of Dr Tung-Yi Lee, who released to me the un-published plate reconstruction map shown in Fig. 7. The text was improved by com- 
ment from Prof. M. S. Srinivasan and an anonymous reviewer. I appreciate the help of Ms K.-H. Hsu for quality illustration.

\section{REFERENCES}

Abbott, L. D., (1995) Neogene tectonic reconstruction of the Adebert-Finisterre-New Britain collision, northern Papua New Guinea. Journal of Southeast Asian Earth Sciences 11, 33-51.

Andrews, J. C., Lawrence, M. W. and Nilsson, C. S., (1980) Observations of the Tasman Front. Journal of Physical Oceanography 10, 1854-1869.

Andrijanic, S., (1988) Geographical distribution of living planktonic foraminifera (Protozoa) off the East coast of Australia. Australian Journal of Marine and Freshwater Research 39, 71-85.

Audley-Charles, M. G., Carter, D. J. and Milsom, J. S., (1972) Tectonic development of Eastern Indonesia in relations to Gondwanland dispersal. Nature Physical Science 239, 35-39.

Backus, R. H. (1986) Biogeographic boundaries in the open ocean. In Pelagic Biogeography. UNESCO Techniques in Marine Science, 49, pp. 9-13.

Barton, C. E. and Bloemendal, J. (1986) Paleomagnetism of sediments collected during Leg 90, southwest Pacific. In Initial Reports of the DSDP, ed. J. P. Kennett, C. C. von der Borch et al., Vol. 90, pp. 1273-1316. U.S. Printing Office; Washington D.C.

Bary, B. M., (1959) Species of zooplankton as a means of identifying different surface waters and demonstrating their movements and mixing. Pacific Science 13, 14-54.

Bé, A. W. H. (1977) An ecological, zoogeographic and taxonomic review of recent planktonic foraminifera. In Oceanic Micropaleontology, ed. T. S. Ramsay, Vol. 1, pp. 1-100. Academic Press, London.

Bé, A. W. H. and Toderlund, D. S. (1971) Distribution and ecology of living planktonic foraminifera in surface waters of the Atlantic and Indian Oceans. In The Micropaleontology of Oceans, ed. B. M. Funnell and W. R. Riedel, pp. 105-149. Cambridge University Press.

Berggren, W. A., Kent, D. V. and van Couvering, J. A. (1985) Neogene geochronology and chronostratigraphy. In The Chronology of the Geological Record, ed. N. J. Snelling, pp. 211260. Geological Society of London, London.

Bradford-Grieve, J. M., Lewis, K. B. and Stanton, B. R., (1991) Advances in New Zealand oceanography. New Zealand Journal of Marine and Freshwater Research 25, 429-441.

Brandt, S. B. and Wadely, V. A., (1981) Thermal fronts as ecotones and zoogeographic barriers in marine and freshwater systems. Proceedings of the Ecological Society of Australia 11, 13-26.

Ciesielski, P. F. and Weaver, F. M., (1974) Early Pliocene temperature changes in the Antarctic seas. Geology 2, 511-515.

Denham, R. N. and Crook, F. J., (1976) The Tasman Front. New Zealand Journal of Marine and Freshwater Research 10, 15-30.

Eade, J. V. (1973) Geographical distribution of living planktonic foraminifera in the Southwest Pacific. In Oceanography of the South Pacific, ed. R. Fraser, pp. 240-256. New Zealand National Commission for UNESCO, Willington.

Elmstrom, K. M. (1985) Late Neogene paleoceanography of the Southwest Pacific: from oxygen and carbon and planktonic foraminiferal faunal evidence of DSDP Sites 588, 590A and 284. MS Thesis, University of Rhode Island. p. 192.

Elmstrom, K. M. and Kennett, J. P. (1986) Late Neogene paleoceanographic evolution of site 590: Southwest Pacific. In Initial Reports of the DSDP, ed. J. P. Kennett, C. C. von der Borch et al., pp. 1361-1381. U.S. Government Printing Office, Washington D.C.

Godfrey, J. S., Cresswell, G. R., Golding, T. J. and Pearce, A. F., (1980) The separation of the East Australian Current. Journal of Physical Oceanography 10, 430-440.

Hayward, B. W., (1983) Planktonic foraminifera (Protozoa) in New Zealand waters: a taxonomic review. New Zealand Journal of Zoology 19, 79-124.
Hamilton, W., (1979) Tectonics of the Indonesian region. U.S. Geological Survey Paper 1078, 345.

Heath, R. A., (1985) A review of the physical oceanography of the seas around New Zealand. New Zealand Journal of Marine and Freshwater Research 19, 79-124.

Hodell, D. A. and Kennett, J. P., (1986) Late Miocene-early Pliocene stratigraphy and paleoceanography of the south Atlantic and southwest Pacific oceans: a synthesis. Paleoceanography 1, 285-311.

Hodell, D. A. and Venz, K. (1992) Towards a high-resolution stable isotopic record of the Southern Ocean during the PliocenePleistocene (4.8 to $0.8 \mathrm{Ma})$. In The Antarctic Paleoenvironment: A Perspective on Global Change, Part 1, ed. J. P. Kennett and D. A. Warnke, Vol. 56, pp. 265-310. Antarctic Research Series, American Geophysical Union, Washington D.C..

Hodell, D. A. and Warnke, D. A., (1991) Climatic evolution of the Southern Ocean during the Pliocene Epoch from 4.8 to 2.6 million years ago. Quaternary Science Review 10, 205-214.

Keany, J., (1978) Paleoclimatic trends in early and middle Pliocene deep-sea sediments in the Antarctic. Marine Micropaleontology 3, 35-49.

Kennett, J. P. (1986) Miocene to early Pliocene oxygen and carbon isotope stratigraphy in the southwest Pacific, Deep Sea Drilling Project Leg 90. In Initial Reports of the DSDP, ed. J. P. Kennett, C. C. von der Borch et al., pp. 1384-1411. U.S. Government Printing Office, Washington D.C.

Kennett, J. P., Keller, G. and Srinivasan, M. S. (1985) Miocene Planktonic foraminiferal biogeography and paleoceanographic development of the Indo-Pacific region. In The Miocene Ocean: Paleoceanography and Biogeography, ed. J. P. Kennett, Vol. 163, pp. 197-236. The Geological Society Memoirs, Geological Society of America, Boulder.

Kennett, J. P., Shackleton, N. J., Margolis, S. V., Goodney, D. E., Dudley, W. C. and Kroopnick, P. M., (1979) Late Cenozoic oxygen and carbon isotope history and volcanic ash stratigraphy: DSDP Site 284, South Pacific. American Journal of Science 279, 52-69.

Kennett, J. P. and Vella, P. (1975) Late Cenozoic planktonic foraminifera and paleoceanography at DSDP Site 284 in the cool subtropical south Pacific. In Initial Reports of the DSDP, ed. J. P. Kennett and R. E. Houtz, Vol. 279, pp. 769-799. U.S. Government Printing Office, Washington D.C.

Kustanowich, S., (1962) Distribution of planktonic forminifera in surface sediments of the south-west Pacific Ocean. New Zealand Journal of Geology and Geophysics 6, 534-556.

Lee, T-Y. and Lawver, L. A., (1995) Cenozoic plate reconstruction of Southeast Asia. Tectonophysics 251, 85-138.

Ludwig, J. A. and Reynolds, J. F. (1988) Statistical Ecology, p. 337. Wiley, New York.

Martínez, J. I., (1994) Late Pleistocene paleoceanography of the Tasman Sea: Implications for the dynamics of the warm pool in the western Pacific. Palaeogeography, Palaeoclimatology and Palaeoecology 112, 19-62.

Mulhearn, P. J., (1983) Deep currents of the northen Tasman Sea Basin. Deep-sea Research 30, 1119-1126.

Mulhearn, P. J., (1987) The Tasman Front: a study using satellite infrared imagery. Journal of Physical Oceanography 17, 1148-1155.

Mulhearn, P. J., Filloux, F. E. M., Bindoff, N. L. and Ferguson, I. J., (1986) Abyssal currents during the formation and passage of a warm-core ring in the East Australian Current. Deep-sea Research 33, 1563-1576.

Parker, F. L. and Berger, W. H., (1971) Faunal and solution patterns of plantonic foraminifera in surface sediments of the South Pacific. Deep-sea Research 18, 73-107.

Pielou, E. C. (1984) The Interpretation of Ecological Data. Wiley, New York.

Reid, J. L. (1981) On the mid-depth circulation of the world ocean. In Evolution of Physical Oceanography, ed. B. A. Warren and C. Wunsch, pp. 70-111. MIT Press, Cambridge.

Shackleton, N. J. and Kennett, J. P. (1975) Late Cenozoic oxygen and carbon isotopic changes at DSDP Site 284: Implications for glacial history of the northern hemisphere and Antarctica. In 
Initial Reports of the DSDP, ed. J. P. Kennett and R. E. Houtz, Vol. 29, pp. 801-807. Government Printing Office, Washington D.C.

Stanton, B. R., (1979) The Tasman Front. New Zealand Journal of Marine and Freshwater Research 13, 201-214.

Stanton, B. R., (1981) An oceanographic survey of the Tasman Front. New Zealand Journal of Marine and Freshwater Research 15, 289-297.

Strass, V. H., (1992) Chlorophyll patchiness caused be mesoscale upwelling at fronts. Deep-sea Research 39, 75-96.

Tate, P. M., Jones, I. S. F. and Hamon, B. V., (1989) Time and space scales of surface temperatures in the Tasman Sea, from satellite data. Deep-sea Research 36, 419-430.

van Andel, TjH, Heath, G. R. and Moore, T. C. Jr (1975) Cenozoic History and Paleoceanography of the Central Equatorial Pacific Ocean. Geological Society Memoirs, 143, p. 134. Geological Society of America, Boulder.
Warren, B. A. (1970) General circulation of the South Pacific. In Scientific exploration of the South Pacific, ed. W. S. Wooster, pp. 33-49. National Academy of Sciences, Washington, D.C..

Webb, P. N., Harwood, D. M., McKelvey, B. C., Mercer, J. H. and Stott, L. D., (1984) Cenozoic marine sedimentation and ice volume variation on the East Antarctic craton. Geology 12, 287-291.

Wei, K.-Y. (1992) Evolution of the planktic foraminiferal clade Globoconella during the late Neogene: paleoceanographic modulation. In Pacific Neogene: Environment, Evolution and Events, ed. R. Tsuchi and J. C. Ingle, pp. 183-204. University of Tokyo Press.

Wei, K.-Y. and Kennett, J. P. (1988) Phyletic gradualism and punctuated equilibrium in the late Neogene planktonic foraminifera clade Globoconella. Paleobiology, 14, 345-363.

Williams, D. F., Sommer, M. A. and Bender, M. L., (1977) Carbon isotopic composition of recent planktonic foraminifera of the Indian Ocean. Earth and Planetary Science Letters 36, 391-403. 